\title{
Simultaneous scar-less laparoscopic cholecystectomy with abdominoplasty
}

\section{Abdominoplasti ile eşzamanlı skarsız laparoskopik kolesistektomi}

\author{
Mehmet Gençtürk ${ }^{1}$, Hasan Erdem ${ }^{1}$, Selim Sözen ${ }^{2}$
}

\begin{abstract}
With abdominoplasty, loosening and sagging problems caused by excessive weight loss are corrected. After bariatric surgery, especially Roux-en-Y gastric bypass (RYGB), the frequency of gallstone formation increases compared to the normal population due to rapid weight loss. Even if the patient is asymptomatic, it is important to perform an abdominal ultrasound examination of all patients who admit for abdominoplasty, especially following postoperative weight loss for morbid obesity. In this study, we tried to state that scarless laparoscopic cholecystectomy and abdominoplasty can be performed safely.
\end{abstract}

Keywords: bariatric surgery, cholecystectomy, abdominoplasty

Öz

Karın germe ameliyatı ile aşırı kilo vermeye bağlı oluşan gevşeme ve sarkma problemleri düzeltilir. Bariyatrik cerrahi, özellikle de Roux-en-Y gastrik bypass (RYGB) sonrasında, hızlı kilo kaybından dolayı safra taşı oluşum sıklığı normal populasyona göre artar. Hasta asemptomatik olsa bile, özellikle morbid obezite için ameliyat sonrası kilo kaybını takiben, abdominoplasti için gelen tüm hastaların abdominal ultrason muayenesi yapılması önem arzeder. Bu çalışmada, izsiz laporoskopik kolesistektomi ve abdominoplastinin güvenli bir şekilde uygulanabileceğini ifade etmeye çalıştık.

Anahtar Kelimeler: bariatrik cerrahi, kolesistektomi, abdominoplasti
1 İstanbul Obezite Cerrahisi (IOC) Clinic, Kurtköy Ersoy Hospital, Istanbul, Turkey.

${ }^{2}$ Sözen Surgery Clinic, Istanbul, Turkey. ID

MG: 0000-0002-6172-0736

HE: 0000-0002-2178-7362

SS: 0000-0003-2006-9198

Informed Consent: The written consent was received from the patient who was presented in this study.

Hasta Onamı: Çalışmada sunulan hastadan yazılı onam alınmıștır

Conflict of Interest: No conflict of interest was declared by the authors.

Çıkar Çatışması: Yazar çıkar çatışması bildirmemiștir.

Financial Disclosure: The authors declared that this case has received no financial support. Finansal Destek: Yazarlar bu olgu için finansal destek almadıklarını beyan etmişlerdir.

Geliş Tarihi / Received: 19.11.2020

Kabul Tarihi / Accepted: 08.03.2021

Yayın Tarihi / Published: 01.04.2021

Sorumlu yazar / Corresponding author:

Selim Sözen

Adres/Address: Sözen Surgery Clinic, Istanbul, Turkey.

e-mail: selimsozen63@yahoo.com

Tel/Phone: +90 5055979773

Copyright $\odot$ ACEM 


\section{Introduction}

Today, abdominoplasty is the most commonly used procedure among body shaping procedures [1]. With this surgical intervention, while loosening and sagging problems caused by excessive weight loss are corrected, the body image and quality of life of the patients also improve [2-4]. After bariatric surgery, especially Roux-en-Y gastric bypass, the frequency of gallstone formation increases compared to the normal population due to rapid weight loss $[5,6]$. Supersaturation of hepatic bile with cholesterol, gallbladder stasis and increased concentration of mucin in the bile are the possible causes [7].

The objective of this study was to present the phenomenon of laparoscopic cholecystectomy and abdominoplasty which we diagnosed at the same period the abdominal laxation, diastases of muscle recti and cholelithiasis without leaving any trocar entrance mark.

\section{Case Presentation}

Our patient was 24 years old male patient presented to our hospital with abdominal wall laxity after massive weight loss of about 30 kilograms. He came seeking for a cosmetic procedure (abdominoplasty) to reduce the abdominal wall laxity and skin excess. During the clinical follow-up, he presented three recurrent biliary colic and recurrent attacks of abdominal pain in right upper quadrant. Abdominal ultrasound examination was performed and revealed chronic calcular cholecystitis with multiple gall bladder stones with non-dilated common bile duct and no manifestations of jaundice. The initial plan of management of the patient was to combine both the abdominoplasty procedure with laparoscopic cholecystectomy.

The surgery was started in supine position under general anesthesia. At the beginning of the intervention the plastic surgeon started marking the abdominal flap. An extended Pfannenstiel incision and the generation of the abdominal skin flap were made up to the xiphoid process. On the muscular wall a $10 \mathrm{~mm}$ Hasson trocar was placed at the umbilical level to generate pneumoperitoneum and was used as a chamber port. Next, $5 \mathrm{~mm}$ trocars were introduced under direct view. The position of the trocars can be seen in Figure 1. Then the patient was placed in a reverse Trendelenburg position of $30^{\circ}$ while rotating the table to left side by $15^{\circ}$. Laparoscopic cholecystectomy was performed. Cystic artery and cystic duct were identified, clamped, and divided. The gallbladder was removed through epigastric midline port using retrieval bag. Abdominal wall parts were closed with non-absorbable suture material. The patient was repositioned in supine position. Abdominoplasty, that is, rectus plication, neo-omphaloplasty, and dermolipectomy of infra-umbilical region was performed. Abdominoplasty wound was closed in layers with a suction drain in situ in the plane of dissection, that is, in between the rectus sheath and the fat layer and flap held with tight dressing. The procedure of combined abdominoplasty and cholecystectomy was completed without leaving any signs of cholecystectomy, and this led to a better cosmetic result from the patients' point of view. There was no complication from both procedures, and full ambulation was obtained post operatively. The patient's consent was obtained for this case study.

\section{Discussion}

Standard abdominoplasty is generally applied in patients with upper and sub-umbilical skin laxity in the area limited to the anterior aspect of the lower body. An incision is made in the lower abdominal area that will remain in a bikini or underwear, and a second incision must be made around the umbilicus. The skin and fat layer are separated from the abdominal wall up to the lower border of the ribs. The abdominal muscles are tightened by a surgical procedure called plication. Excess skin and adipose tissue are excised. The operation is terminated by placing drains on both sides of the abdomen $[8,9]$.

Figure 1. The position of the trocars.

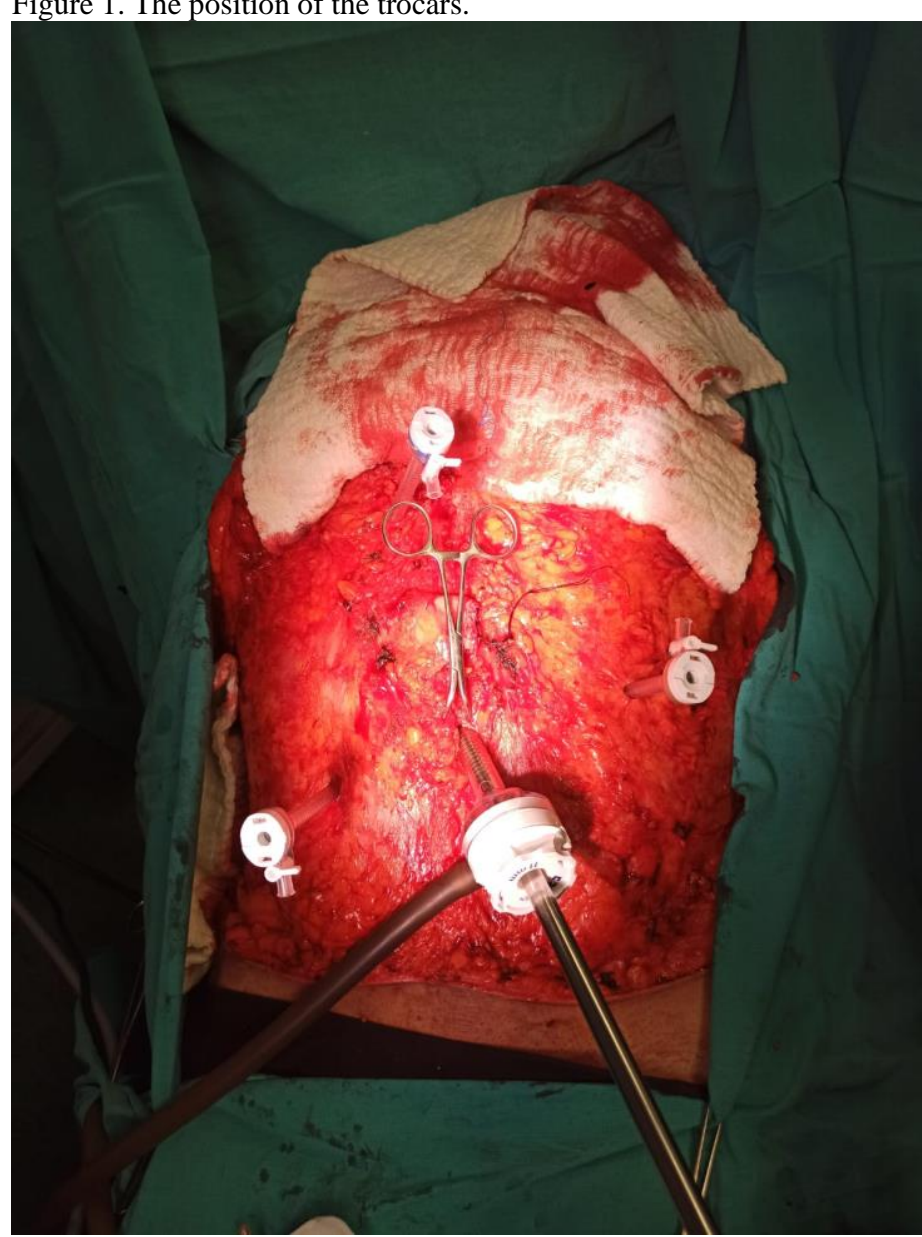

The amount of cholesterol and mucin in bile increases after bariatric surgery. As fatty food intake will decrease after bariatric surgery, gallbladder movements decrease. Bile salt release decreases with weight loss. For these reasons, the possibility of stone formation in the gallbladder increases with rapid weight loss after bariatric surgery. Too high BMI (body mass index) of the patient before bariatric surgery and losing more than $25 \%$ of his weight before bariatric procedure are also risk factors for stone development [5-7].

The combined abdominoplasty with cholecystectomy was performed in 3 cases laparoscopically in 2012 with no complications and this led to a better cosmetic result from the patients' point of view [10]. Combined laparoscopic cholecystectomy with abdominoplasty were achieved with successful outcome without any complications [11]. Combining two or multiple abdominal procedures may reduce the potential risks of multiple anesthesia for each procedure, shorten total hospital stay and operating room time, and, perhaps most importantly for the patient, reduce costs and time off work [12]. 
Scarless cholecystectomy has been described in the past using the single port technique through the umbilicus and natural orifice translumenal endoscopic surgery (NOTES) from the vagina [13-15]. Our technique is a modification of the routine 'French technique' [16, 17] used for laparoscopic cholecystectomy, where all ports were placed directly on the fascia and muscle wall during abdominoplasty, thus avoiding visible scars of cholecystectomy. Good surgical teams can safely and effectively combine abdominoplasty with intra-abdominal procedures [18]. The combined surgery in the same surgical time allows to avoid skin incisions and reduce the potential risks of multiple anesthesia for each procedure, and it also reduces costs and postoperative recovery [19].

\section{Conclusion}

In the present study, even if the patient is asymptomatic, we recommend abdominal ultrasound examination of all patients who admit for abdominoplasty following postoperative weight loss especially for morbid obesity.

The present study also suggests the technique we use for the port placement because it is convenient, easy, and has no side effects on patients compared to other techniques.

\section{References}

1. Zammerilla LL, Zou RH, Dong ZM, et al. Classifying severity of abdominal contour deformities after weight loss to aid in patient counseling: a review of 1006 cases. Plast Reconstr Surg. 2014;134:888e-894e.

2. Stuerz K, Piza H, Kinzl JF. The impact of abdominoplasty after massive weight loss: A qualitative study. Ann Plast Surg. 2013;71:547-9.

3. Saariniemi K, Salmi AM, Peltoniemi HH, Helle MH, Charpentier P, Kuokkanen H. Abdominoplasty improves quality of life, psychological distress, and eating disorder symptoms: A prospective study. Plast Surg Int. 2014;2014:197232.

4. Hurvitz KA, Olaya WA, Nguyen A, Wells JH. Evidencebased medicine: Abdominoplasty. Plast Reconstr Surg. 2014;133:1214-21.

5. Iglezias Brando de Oliveira C, Adami Chaim E, da Silva BB. Impact of rapid weight reduction on risk of cholelithiasis after bariatric surgery. Obes Surg. 2003;13:625-628.

6. Jonas E, Marsk R, Rasmussen F, Freedman J. Incidence of postoperative gallstone disease after antiobesity surgery: population-based study from Sweden. Surg Obes Relat Dis. 2010;6:54-8.

7. Fuller W, Rasmussen JJ, Ghosh J, Ali MR. Is routine cholecystectomy indicated for asymptomatic cholelithiasis in patients undergoing gastric bypass? Obes Surg. 2007;17:74751.

8. Logan JM, Broughton G. Plastic surgery: Understanding abdominoplasty and liposuction. AORN J. 2008;88:587-91.

9. Ellison JM, Steffen KJ, Sarwer DB. Body contouring after bariatric surgery. Eur Eat Disord Rev. 2015;23:479-87.

10. Prasad MB, Surapaneni SR, Dabade SS. Scarless cholecystectomy: laparoscopic cholecystectomy with abdominoplasty. Indian J Surg. 2012;74:486-8.

11. Ibrahim AAM. Simultaneous laparoscopic cholecystectomy with abdominoplasty. Int Surg J. 2017;4:2139-42 .

12. Özgur F, Aksu A, Özkan O, Hamaloglu E. The advantages of simultaneous abdominoplasty, laparoscopic cholecystectomy, and incisional hernia repair. European J Plastic Surg. 2002;25:271-4

13. Iannelli A, Schneck AS, Ioia G, Gugenheim J Single Incision laparoscopic surgery cholecystectomy: a preliminary experience. Surgl Laparosc Endosc Percutan Tech. 2010;20:89-91.

14. Zornig C, Mofid H, Emmermann A, Alm M, von Waldenfels HA, Felixmuller C. Scarless cholecystectomy with combined transvaginal and transumbilical approach in a series of 20 patients. Surg Endosc. 2008;22:1427-9.

15. Cuesta MA, Berends F, Veenhof AA. The "invisible cholecystectomy": a transumbilical laparoscopic operation without a scar. Surg Endosc. 2008;22:1211-3.

16. Bailey RW, Zucker KA, Flowers JL, Scoville WA, Graham SM, Imbembo AL. Laparoscopic cholecystectomy: experience with 375 consecutive patients. Ann Surg. 1991;214:531-40.

17. Kryger ZB, Dumanian GA, Howard MA. Safety issues in combined gynecologic and plastic surgical procedures. Int $\mathrm{J}$ Gynecol Obstetr. 2007;99:257-63.

18. Gemperli R, Neves RI, Bonamichi GT, Bonamichi GT, Ferreira MC, Manders EK. Abdominoplasty combined with other intra-abdominal procedures. Ann Plast Surg. 1992;29:18-22.

19. Sánchez-Cordero S, Cambier B, Roriz R, Salazar A, Vilallonga R. Combined surgery: abdominoplasty and abdominal laparoscopic surgery in one surgical time. Bariátrica \& Metabólica Ibero-Americana. 2019; 9.3.8: 261820. 